Rinny Kartini, Zakiyah, Sari Narulita

Hubungan Mekanisme Koping Terhadap Tingkat Stres Prajurit TNI Angkatan Darat

\title{
Hubungan Mekanisme Koping Terhadap Tingkat Stres Prajurit TNI Angkatan Darat
}

\author{
Rinny Kartini ${ }^{1}$, Zakiyah $^{2}$, Sari Narulita ${ }^{3}$ \\ ${ }^{1}$ Program Studi Sarjana Keperawatan Universitas Binawan \\ ${ }^{2,3}$ Program Studi Ilmu Keperawatan Universitas Binawan \\ Korespondensi penulis: Zakiyah@binawan.ac.id
}

\begin{abstract}
Abstrak
Stres adalah kontributor utama penyakit mental dan fisik pada setiap orang di segala usia, dan sebagai penjaga keamanan dan stabilitas negara, kondisi pemaparan berulang terhadap situasi pertempuran dan stressor lainnya dapat mempengaruhi kesehatan mental para tentara. Stress merupakan segala situasi dimana tuntutan non-spesifik mengharuskan seorang individu untuk berespons atau melakukan tindakan, dan mekanisme koping adalah cara yang digunakan individu dalam menyelesaikan masalah, mengatasi perubahan yang terjadi, dan situasi yang mengancam, baik secara kognitif maupun perilaku. Penelitian ini bertujuan untuk mengetahui hubungan mekanisme koping terhadap tingkat stress pada prajurit TNI-AD di Kesatuan Brigif Para Raider 17/Kujang 1 Divif 1 Kostrad Cijantung Jakarta Timur. Desain penelitian ini yaitu deskriptif korelatif dengan pendekatan cross sectional. Sampel penelitian ini adalah 133 prajurit tingkat satu yang ditentukan menggunakan teknik purposive sampling. Instrumen yang digunakan adalah Ways of coping dan Depressions Anxiety and Stress Scale. Data yang telah terkumpul diolah dengan menggunakan uji korelasi Spearman Rho. Hasil analisis univariat menunjukkan mekanisme koping destruktif (73,7\%) dan tingkat stress berat (48,9\%). Hasil analisis bivariat menunjukkan adanya hubungan antara mekanisme koping terhadap tingkat stress pada prajurit TNI-AD dengan hasil signifikan atau $p$-value adalah 0,000 dimana $(p<0,005)$ dan nilai coefficient correlation berjumlah 0,614. Terdapat hubungan yang signifikan antara mekanisme koping dengan tingkat stress prajurit TNI-AD di Kesatuan Brigif Para Raider 17/Kujang 1 Divif 1 Kostrad Cijantung Jakarta Timur. Diperlukan peningkatan pemahaman dan keterampilan mekanisme koping konstruktif dan manajemen stress pada prajurit.
\end{abstract}

Kata kunci: mekanisme koping; stres; TNI-AD

PENDAHULUAN

World Health Organization (WHO, 2012) menyebutkan bahwa sekitar 450 juta orang didunia mengalami masalah gangguan kesehatan jiwa. Di Indonesia, kejadian stress masih tinggi dan sangat bervariasi pada berbagai kelompok. Hasil Riset Kesehatan Daerah (Riskesdas) tahun 2007 menunjukkan bahwa $11,6 \%$ penduduk Indonesia berusia 15 tahun ke atas mengalami gangguan mental emosional, dan pada tahun 2013 angka tersebut menunjukkan penurunan menjadi $6 \%$. Profil kesehatan provinsi Daerah Khusus Ibukota (DKI) Jakarta (2012) menyebutkan bahwa sekitar 1,33 juta penduduk diperkirakan mengalami gangguan kesehatan mental atau stress. Angka tersebut mencapai $14 \%$ dari total penduduk dengan tingkat stress akut (stress berat) mencapai 13\%. Data Dinas Kependudukan dan 
Rinny Kartini, Zakiyah, Sari Narulita

Hubungan Mekanisme Koping Terhadap Tingkat Stres Prajurit TNI Angkatan Darat

Catatan Sipil DKI Jakarta menunjukkan jumlah penduduk DKI Jakarta saat ini mencapai 9,5 juta jiwa. Jumlah penduduk yang stress mencapai 1,33 juta (14 persen dari 9,5 juta), sementara stress berat mencapai 95.000-285.000 orang (1-3 persen dari 9,5 juta) (PDKI, 2012).

WHO (2014) menyebutkan bahwa dibanyak negara, sebesar $8 \%$ penyakit yang ditimbulkan akibat kerja adalah stress. Departemen Dalam Negeri Amerika Serikat memperkirakan, $40 \%$ dari kasus keluar masuknya tenaga kerja disebabkan karena masalah stress (Losyk, 2007). Hasil penelitian Labour Force Survey pada tahun 2014 menemukan adanya 440.000 kasus stress akibat kerja di Inggris dengan angka kejadian sebanyak 1.380 kasus per 100.000 pekerja yang mengalami stress akibat kerja.

Stres akibat kerja juga dialami oleh para tentara yang memiliki tugas sebagai penjaga keamanan dan stabilitas negara. Hasil penelitian Kaikkonen \& Laukkala (2016) menyebutkan bahwa pemaparan berulang terhadap situasi pertempuran dan stressor lainnya dapat mempengaruhi kesehatan mental para tentara melalui berbagai cara. Hyun \& Lee (2008) menyebutkan bahwa tentara di korea mengalami tingkat stress dengan rata-rata 2,53 dari kisaran nilai 1,00-4,35, dan memiliki gejala stress dengan rata-rata 0,95 dari kisaran nilai 0,04-2,83, dengan hal yang mempengaruhi gejala stresnya adalah faktor eksternal dalam militer $(\mathrm{P}<0.001)$, peran dan faktor hubungan $(\mathrm{p}<0,001)$, faktor kerja $(\mathrm{p}<0,01)$, dan gaya koping $(\mathrm{p}<0,001)$. Koping fungsional memiliki hubungan dengan negatif atau tidak adanya skala distress, dan koping disfungsional memiliki hubungan dengan positif atau adanya distress (Nakkas, Annen, \& Brand, 2016).

Stress dapat menimbulkan tuntutan yang besar pada seseorang, dan jika orang tersebut tidak dapat mengadaptasi, maka dapat terjadi penyakit (Perry \& Potter 2005); dan stres adalah kontributor utama penyakit mental dan fisik pada setiap orang di segala usia (APA, 2012, dalam Zakiyah, 2016). Stress adalah segala situasi dimana tuntutan nonspesifik mengharuskan seorang individu untuk berespon atau melakukan tindakan (Selye, 1976, dalam Perry \& Potter, 2005). Stress merupakan sebuah bentuk respon tubuh seseorang yang memiliki beban pekerjaan berlebihan. Jika seseorang tersebut tidak sanggup mengatasinya, maka orang tersebut dapat mengalami gangguan dalam menjalankan pekerjaan (Hawari, 2011). Stress kerja pada prajurit TNI-AD dapat dipengaruhi oleh disiplin militer. Kadang perintah atasan sering berubah, tidak jelas dan berlebihan diluar jam dinas. Selanjutnya, terkadang pun terjadi pemaksaan kehendak dan tanpa memikirkan kepentingan bawahannya. Selain itu dalam lingkungan kerja militer memiliki aturan bahwa perintah komandan bersifat mutlak (prerogerative) (Pusat Kesejahteraan Infanteri Mabes-AD RI, 2005).

Videbeck (2008) menyebutkan bahwa untuk menghadapi keadaan stres seseorang harus beradaptasi dengan stressor dalam berespon atau melakukan tindakan. Respon atau tindakan ini termasuk respons fisiologis dan psikologis. Respon adaptif psikologis dari stresor tersebut disebut sebagai mekanisme koping. Mekanisme koping adalah cara yang 
Rinny Kartini, Zakiyah, Sari Narulita

Hubungan Mekanisme Koping Terhadap Tingkat Stres Prajurit TNI Angkatan Darat

dilakukan individu dalam menyelesaikan masalah, menyesuaikan diri dengan perubahan, serta respon terhadap situasi mengancam (Keliat, 1999). Menurut Stuart (2016), mekanisme koping adalah semua upaya yang diarahkan untuk mengelola stress yang dapat bersifat konstruktif dan destruktif.

Pusat Kesejahteraan Infanteri Mabes-AD RI, 2005, menyebutkan bahwa salah satu pasukan elit infanteri Tentara Nasional Indonesia (TNI) adalah Batalyon Raider. Unit infanteri ini dilatar belakangi dengan taktik prtempuran "Raid" ("Depredasi"). Selama ini, ada dua kualifikasi yang dimiliki oleh prajurit pilihan di Kostrad , yakni intai tempur yang bertugas membuka jalan bagi pasukan reguler, serta lintas udara atau linud. Raider kemampuan khusus prajurit untuk menghadapi terorisme, antigerilya maupun perang berlarut. Sedangkan para adalah kualifikasi terjun payung. Secara umum, kemampuan raider biasanya digunakan untuk mobilisasi pasukan, utamanya menggunakan helikopter atau yang dinamakan mobilisasi udara (mobud). Data yang didapatkan dari Kesatuan Brigif 17 untuk kejadian stress pada prajurit tahun 2016 menunjukkan bahwa sekitar 5\% dari 364 personilnya mengalami stress. Berdasarkan studi pendahuluan yang dilakukan dengan wawancara pada beberapa prajurit selalu dihadapkan pada kegiatankegiatan yang diadakan oleh kesatuan yang memicu terjadi stressor. Stress yang sering dihadapi juga salah satunya adalah mobilitas yang sangat tinggi saat melaksanakan tugasnya.

Berdasarkan paparan di atas, penulis berkeinginan untuk melakukan penelitian yang bertujuan untuk mengetahui hubungan mekanisme koping terhadap stress pada prajurit TNI-AD di Kesatuan Brigif Para Raider 17/Kujang 1 Divif 1 Kostrad Cijantung Jakarta Timur. Selain itu penelitian ini dilakukan terhadap prajurit TNI-AD, dimana Prajurit TNI$\mathrm{AD}$ termasuk individu yang jarang dilakukan penelitian sehingga penelitian ini menjadi menarik dan unik.

\section{METODE}

Penelitian ini menggunakan desain deskriptif korelatif dengan pendekatan cross sectional yang dilakukan pada 133 Prajurit TNI-AD di Kesatuan Kesatuan Brigif Para Raider 17/Kujang 1 Divif 1 Kostrad Cijantung Jakarta Timur. Sampel diambil dengan metode purposive sampling. Pengumpulan data tingkat stress dilakukan dengan menggunakan instrument Depression Anxiety and Stress Scale (DASS) yang hanya diambil 14 item, yaitu pertanyaan no: $1,6,8,11,12,14,18,22,27,29,32$, 33, 35, dan 39 yang dikembangkan oleh Lovibond \& Lavibond (1995) dan diadopsi dari Damanik (2006) dengan nilai validitas $0,48-0,68$ dan nilai reliabilitas: 0,9483. Pengumpulan data mekanisme koping dilakukan dengan menggunakan kuesioner Ways of Coping Sscales yang dibuat oleh Folkman S et.al (1986). Selanjutnya data dianalisis dengan menggunakan uji korelasi Spearman Rank (rho). 
Rinny Kartini, Zakiyah, Sari Narulita

Hubungan Mekanisme Koping Terhadap Tingkat Stres Prajurit TNI Angkatan Darat

HASIL

Hasil penelitian didapatkan tentang mekanisme koping (Tabel 1.1), tingkat stres (tabel 1.2), dan hubungan mekanisme koping terhadap tingkat stress pada Prajurit TNI-AD di Kesatuan Kesatuan Brigif Para Raider 17/Kujang 1 Divif 1 Kostrad Cijantung Jakarta Timur, sebagai berikut:

Tabel 1.1 Mekanisme Koping Prajurit TNI-AD di Kesatuan Kesatuan Brigif Para Raider 17/Kujang 1 Divif 1 Kostrad Cijantung Jakarta Timur

\begin{tabular}{ccc}
\hline Mekanisme Koping & Frekuensi & Persentase \% \\
\hline Konstruktif & 35 & 26,3 \\
\hline Destruktif & 98 & 73,7 \\
\hline Total & 133 & 100
\end{tabular}

Tabel 1.2 Mekanisme Koping Prajurit TNI-AD di Kesatuan Kesatuan Brigif Para Raider 17/Kujang 1 Divif 1 Kostrad Cijantung Jakarta Timur

\begin{tabular}{ccc}
\hline Stress & Frekuensi & Persentase \% \\
\hline Ringan & 22 & 16,5 \\
\hline Sedang & 46 & 34,6 \\
\hline Berat & 65 & 48,9 \\
\hline Total & 133 & 100 \\
\hline
\end{tabular}

Tabel 1.3 Hubungan Mekanisme Koping Terhadap Tingkat Stres Prajurit TNI-AD di Kesatuan Kesatuan Brigif Para Raider 17/Kujang 1 Divif 1 Kostrad Cijantung Jakarta Timur

\begin{tabular}{|c|c|c|c|c|c|c|c|c|c|c|c|}
\hline \multirow{2}{*}{\multicolumn{2}{|c|}{ Variabel }} & \multicolumn{6}{|c|}{ Stress } & \multirow[b]{2}{*}{ है } & \multirow[b]{2}{*}{$\%$} & $\begin{array}{c}\mathbf{r} \\
\text { tabel }\end{array}$ & $\begin{array}{c}\text { p- } \\
\text { value }\end{array}$ \\
\hline & & 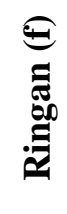 & $\Delta^{\circ}$ & 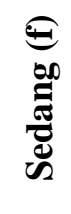 & $b^{0}$ & $\underset{\Theta}{\Theta}$ & $\Delta^{2}$ & & & \multirow{4}{*}{$\begin{array}{c}0,61 \\
4\end{array}$} & \multirow[t]{4}{*}{0,000} \\
\hline \multirow{2}{*}{$\begin{array}{c}\text { Mekanisme } \\
\text { koping }\end{array}$} & Konstruktif & 15 & 11,3 & 20 & 15,0 & 0 & 0 & 35 & 26,3 & & \\
\hline & Destruktif & 7 & 5,3 & 26 & 19,5 & 65 & 48,9 & 98 & 73,7 & & \\
\hline \multicolumn{2}{|c|}{ Total } & 22 & 16,6 & 46 & $\mathbf{3 4 , 5}$ & 65 & 48,9 & 133 & 100 & & \\
\hline
\end{tabular}

\section{PEMBAHASAN}

Hasil penelitian menunjukkan bahwa mekanisme koping Prajurit di Kesatuan Brigif 17 memiliki mekanisme koping destruktif $(73,7 \%)$, dan mengalami stress berat $(48,9 \%)$. Prajurit yang memiliki mekanisme koping konstruktif memiliki tingkat stress ringan dan sedang, sedangkan prajurit yang memiliki mekanisme koping destruktif banyak yang memiliki tingkat stress berat. Hal ini sejalan dengan hasil penelitian Kartika (2012) yang menyebutkan bahwa dari 128 prajurit yang dijadikan responden menunjukkan hanya ada 2 prajurit $(1,6 \%)$ yang mengalami stress berat dan 113 prajurit $(88,3 \%)$ yang mengalami stress ringan. 
Rinny Kartini, Zakiyah, Sari Narulita

Hubungan Mekanisme Koping Terhadap Tingkat Stres Prajurit TNI Angkatan Darat

Selain itu, Hasil penelitian menunjukkan adanya hubungan antara mekanisme koping dengan tingkat stres dengan signifkansi sebesar $p=o, o o o$. Pallant (2007) menyebutkan bahwa taraf signifikansi $\quad \mathrm{p}<0,05$ memprediksikan bahwa variabel independen tersebut mampu memprediksi atau mempengaruhi variabel dependen, sehingga hasil penelitian ini menunjukkan ada hubungan yang signifikan antara mekanisme koping dan stres. Hasil analisa data mekanisme koping terhadap tingkat stress menunjukkan masih banyak prajurit yang mengalami stress berat dengan jumlah 65 orang $(48,9 \%)$ dan mereka lebih cenderung menggunakan mekanisme koping yang destruktif.

Hasil penelitian ini sejalan dengan hasil penelitian yang dilakukan oleh Amirudin (2014) dimana dalam penelitiannya tersebut Jemmi mengatakan bahwa ada hubungan yang signifikan antara stress dan koping, apabila seseorang memiliki koping/ketahanan yang baik maka tingkat stressnya akan menurun. Menurut Stuart dan Sundeen (1995, dalam Nasir 2011) mekanisme koping destruktif adalah mekanisme koping yang menghambat fungsi integrasi, memecah pertumbuhan, menurunkan otonomi dan cenderung menguasai lingkungan. Kategorinya adalah makan berlebihan atau tidak makan, bekerja berlebihan, menghindar.

Kozier (2004) menyebutkan bahwa dalam kondisi tertekan seseorang akan berusaha untuk beradaptasi dan menyelesaikan masalahnya. Pemecahan masalah ini bergantung pada pengalaman dan evaluasi individu, sedangkan efektif atau tidaknya penyelesaian masalah yang digunakan oleh individu sangat bergantung pada lingkungan dimana usaha tersebut dilakukan.

Lazarus dan Folkman (1986) menjelaskan bahwa individu dapat menggunakan baik problem focused coping atau emotion focused coping dalam episode stress mereka, akan tetapi bagaimanapun juga lingkungan dimana situasi ini terjadi juga memberikan kontribusi pada cara penyelesaian yang akan digunakan individu dan efektivitasnya. Aldwin dan Revenson (dalam Ismafiaty, 2011) juga mengatakan bahwa bentuk dari mekanisme koping terdiri dari yang berorientasi pada masalah yang merupakan bentuk mekanisme koping yang berpusat pada masalah atau situasi yang menyebabkan stres. Mekanisme ini meliputi cara-cara yang dilakukan individu secara konsruktif terhadap stres yang dialami individu yang bersangkutan, sehingga individu dapat terbebas dari masalah tersebut.

Adapun mekanisme yang kedua adalah berorientasi pada emosi dimana mekanisme ini mengikutsertakan usaha mengubah emosi, berdasarkan pengalaman yang disebabkan oleh peristiwa yang menimbulkan stress. Nakkas, Annen, \& Brand (2016) menyebutkan tentara yang memiliki koping fungsional memiliki hubungan dengan negatif atau tidak adanya skala distress, dan tentara yang menggunakan koping disfungsional memiliki hubungan dengan positif atau adanya distress

Mekanisme koping yang digunakan oleh prajurit berbeda-beda. Hal ini dapat dipengaruhi oleh berbagai faktor diantaranya faktor kesehatan fisik, faktor keyakinan atau pandangan positif, faktor keterampilan, dan sebagainya. Faktor yang paling mempengaruhi adalah kesehatan fisik, mengingat prajurit erat sekali 
Rinny Kartini, Zakiyah, Sari Narulita

Hubungan Mekanisme Koping Terhadap Tingkat Stres Prajurit TNI Angkatan Darat

hubungannya dengan latihan-latihan fisik dan ketika kesehatannya terganggu dan prajurit mendapatkan stressor maka sangat memungkinkan prajurit menggunakan mekanisme koping yang destruktif.

Pada variabel dependen yaitu tingkat stress, tingkat stress pada prajurit berbeda-beda hal ini dikarenakan respon terhadap stress yang ditimbulkan disetiap prajurit mempunyai perbedaan. Sedangkan prajurit yang mengalami stress sedang terlihat ketika seorang prajurit dihadapkan dengan sebuah tugas yang dianggap sulit dan khawatir tugas tersebut tidak dapat terselesaikan, adapun prajurit yang mengalami stress berat yang disebabkan banyaknya masalah yang dialami baik secara pribaddi amuoun perihal kedinasan di kesatuan.

Peneliti berasumsi bahwa stress yang terjadi pada prajurit dikarenakan ketidakjelasan perintah misalnya prajurit sering mendapat perintah yang berbeda-beda dari komandan maupun senior yanh membuat mereka menjadi bingung. Selain itu ketidakmampuan kontrol diri pada prajurit TNI-AD yang menyebabkan perilakunya diluar kontrol dirinya dan kognitifnya, banyaknya beban dan tekanan yang dialami seama berdinas membuat prajurit kehilangan kontrol diri seperti putus asa, desersi, dan lain-lain.

\section{KESIMPULAN}

Berdasarkan hasil penelitian, dapat disimpulkan bahwa Prajurit TNIAD di Kesatuan Kesatuan Brigif Para Raider 17/Kujang 1 Divif 1 Kostrad Cijantung Jakarta Timur memiliki tingkat stress berat dan memiliki mekanisme koping destruktif, serta adanya hubungan yang signifikan antara mekanisme koping dengan tingkat stress yang dialami Prajurit TNI-AD di Kesatuan Kesatuan Brigif Para Raider 17/Kujang 1 Divif 1 Kostrad Cijantung Jakarta Timur. Perlu dilakukan peningkatan pembinaan yang selama ini telah dilakukan, dan pelatihan tentang manajemen stres khususnya pada Prajurit TNI-AD di Kesatuan Kesatuan Brigif Para Raider 17/Kujang 1 Divif 1 Kostrad Cijantung Jakarta Timur.

\section{DAFTAR PUSTAKA}

Ekasari, A. \& Susanti,N.D. (2009). Hubungan Antara Optimisme dan Penyesuaian Diri dengan Stres. Jurnal Soul. Vol.2, No.2 pp 15-16.

Pusat Kesejahteraan Infanteri Markas Besar Angkatan Darat RI. (2005). Gema Infanteri. (ed.75). Bandung.

Hawari, D. (2011). Manajemen Stres Cemas Dan Depresi. Jakarta: FKUI.

Hyun, HS. \& Lee, IS. (2008). A Study on Stress and Symptoms of Stress in Soldier in The Army. Journal of Korean Academy of Nursing. Volume 38 (2) April 2008. https://www.jkan.or.kr/DOIx.php? $\mathrm{id}=10.4040 / \mathrm{jkan} .2008 .38 .2 .238$

Kaikkonen, NM. \& Laukkala, T. (2016). International Military Operations and Mental Health-A Review. Nordic Journal of Psychiatry. Volume 70. https://www.tandfonline.com/doi/ full/10.3109/08039488.2015.1048 $\underline{718}$.

Keliat, B.A., (1999). Proses Keperawatan Jiwa, Edisi 1, Jakarta : EGC.

Losyk, B. (2007). Kendalikan Stress Anda. Jakarta: Gramedia Pustaka Utama.

Nakkas, C., Annen, H., \& Brand, S. (2016). Psychological Distress and Coping in Military Cadre Candidates. Neuropsychiatric 
Rinny Kartini, Zakiyah, Sari Narulita

Hubungan Mekanisme Koping Terhadap Tingkat Stres Prajurit TNI Angkatan Darat

Disease and Treatment 2016:12:2237-2243.

https://www.ncbi.nlm.nih.gov/pm c/articles/PMC5010160/pdf/ndt12-2237.pdf.

Pallant, J. (2007). SPSS survival manual: A step by step to data analysis using SPSS for windows 3rd Edition. Maidenhead: Open University Press. http://spss.allenandunwin.com.s3website-ap-southeast2.amazoneaws.com.

Perhimpunan Dokter Keluarga Indonesia (PDKI). (2012). Profil Kesehatan Provinsi DKI Jakarta. Departemen Kesehatan. No. 48 pp 110.

Potter, P. \& Perry. (2005). Fundamental of Nursing: Concept, Process, \&
Practice. (Asih, Y. Et. All, penerjemah). Jakarta: EGC.

Stuart, WG., \& Laraia, MT. (2005). Principles and Practice of Psychiatric Nursing. (7th Edition). St. Louis: Mosby.

Riset Kesehatan Dasar. (2013). Prevalensi Gangguan Jiwa Indonesia.

www.depkes.go.id/resources.dow nload/general/Hasil\%20Riskesdas \%202013.pdf. diakses 26 April 2017.

Riset Kesehatan Dasar. (2007). Prevalensi Gangguan Jiwa Indonesia. www.depkes.go.id/resources.dow nload/general/Hasil\%20Riskesdas \%202007.pdf. diakses 26 April 2017. 